Article

\title{
Selective Substitution of 31/42-OH in Rapamycin Guided by an in Situ IR Technique
}

\author{
Shuang Cao ${ }^{1}$, Xinbo Zhou ${ }^{2}$, Yuanshuai Yang ${ }^{1}$, Wu Zhong ${ }^{2, *}$ and Tiemin Sun ${ }^{1, *}$
}

1 Key Laboratory of Structure-Based Drug Design and Discovery, Shenyang Pharmaceutical University, Ministry of Education, Shenyang 110016, China;

E-Mails: caoshuangknight@163.com (S.C.); yangmarshal88@163.com (Y.Y.)

2 Laboratory of Computer-Aided Drug Design \& Discovery, Beijing Institute of Pharmacology and Toxicology, Beijing 100850, China; E-Mail: hapwave@163.com

* Authors to whom correspondence should be addressed; E-Mails: zhongwu@bmi.ac.cn (W.Z.); suntiemin@126.com (T.S.); Tel.: +86-10-66931634 (W.Z.); +86-24-23986398 (T.S.).

Received: 25 April 2014; in revised form: 26 May 2014 / Accepted: 27 May 2014 /

Published: 10 June 2014

\begin{abstract}
An in situ IR technique was applied in the selective synthesis of the key intermediate for rapamycin derivatives, which made the reaction endpoint easily defined. This technology solved a bothersome problem in the preparation of rapamycin derivatives, and based on this technique, the $31-\mathrm{OH}$ and $42-\mathrm{OH}$ of rapamycin were chemically modified by a series of quaternary ammonium salts to generate 11 compounds. The solubility of all these compounds was remarkably improved (25,000 times higher than that of rapamycin) and their structures were confirmed by MS, IR, 1D and 2D NMR techniques.
\end{abstract}

Keywords: rapamycin derivatives; in situ IR; selective substitution; aqueous solubility

\section{Introduction}

Rapamycin (Rapa, Figure 1) is a carboxylic lactone-lactam macrolide derived from the bacterium Streptomyces hygroscopicus [1]. It was originally used as an immunosuppressant in the treatment of organ rejection in transplant recipients, and then as an anti-cancer drug [2]. In recent years, some new applications of rapamycin and rapamycin analogues have been disclosed, such as anti-aging, anti-HIV, and so on [3]. Rapamycin has brought a new dawn to cancer treatment due to its special mechanism of 
inhibiting cancer cell growth via inhibition of the mammalian target of rapamycin (mTOR), which is the key factor in cell proliferation regulation [4].

Figure 1. Structure of rapamycin (Rapa).

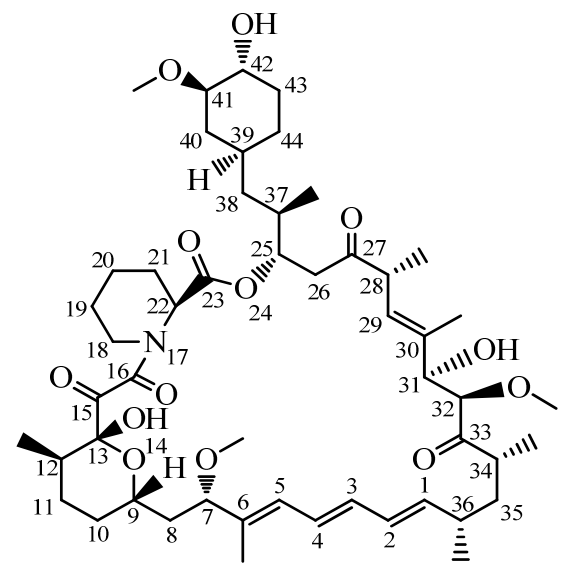

Although Rapa has shown great potential in numerous ways, it also has two severe drawbacks, namely poor aqueous solubility $(2.6 \mu \mathrm{g} / \mathrm{mL})$ [5] and low oral bioavailability (10\%) [6]. To overcome these problems, a number of Rapa derivatives have been developed, the majority of which are derived from modifications on the 42-OH of Rapa. For example, Temsirolimus (CCI-779, Wyeth, Madison, NJ, USA, 2007) [7], Everolimus (RAD001, Novartis, Basel, Switzerland, 2003), and Zotarolimus (ABT 578, Abbott, Chicago, IL, USA, 2006) [2], These successful drugs suggest that the modification on the 42-OH may be a more wise choice to optimize rapamycin, but the selective substitution of $42-\mathrm{OH}$ is very difficult because the structure of Rapa is very complicated and there are three -OHs in the structure thereof.

The traditional avenue for selective synthesis of 42-Rapa derivatives was first reported in US Patent 6277983 [8]. The crucial point of this method is preparation of the intermediate Rapa-31-OTMS (Scheme 1), which is also the key intermediate for preparating 31-Rapa derivatives. However, in practice, we found that though the yield of this preparation could reach up to $70 \%$ (column separation), it is instable, and additionally, a lot of raw material and by-product are comingled with the end-product.

Scheme 1. Synthesis of Rapa-31-OTMS intermediate.

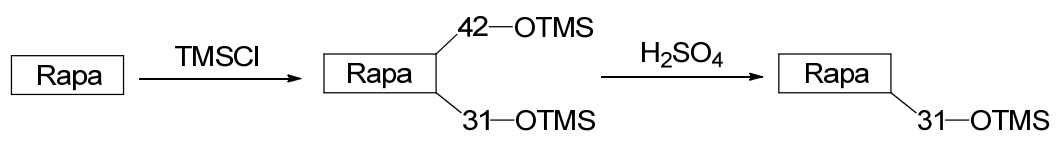

What contributes to this problem is the difficulty in defining a suitable reaction endpoint, in other words, the amount of acid and the reaction time are difficult to control just right. On one hand, it is necessary to use enough acid and the correct reaction time to convert Rapa-31,42-OTMS into Rapa-31-OTMS. On the other hand, too much of them will lead to the decomposition of the Rapa-31-OTMS into Rapa. Moreover, there exists a connection between the amount of acid and the reaction time. The amount of acid can be reduced by extending the reaction time, and vice versa. These problems manifest especially prominently in industrial production.

In view of the high cost of the raw material (Rapa) and the difficulty of accurate control in the traditional method, a new technology is seriously required to solve these problems. Herein, we report 
an application of in situ IR in selective synthesis of the key intermediate for Rapa derivatives. Based on this method, a series of mono-substituted Rapa derivatives with quaternary ammonium groups were obtained, which all had excellent aqueous solubility.

\section{Results and Discussion}

\subsection{In Situ IR}

Through analysis of a series of features in the IR spectrum of Rapa-31-OTMS (Figure 2), the intensity of the absorption peak at $1.055 \mathrm{~cm}^{-1}$, a characteristic peak attributed to -Si-O(C) [9-12], was selected as marker to monitor the levels of Rapa, Rapa-31,42-OTMS and Rapa-31-OTMS indirectly (Figure 3) [13]. The structure of Rapa-31,42-OTMS and Rapa-31-OTMS had been identified by ${ }^{1}$ H-NMR (Supplementary Material).

Figure 2. Expanded solid state FT-IR spectra for Rapa, Rapa-31-OTMS and Rapa-31,42-OTMS.

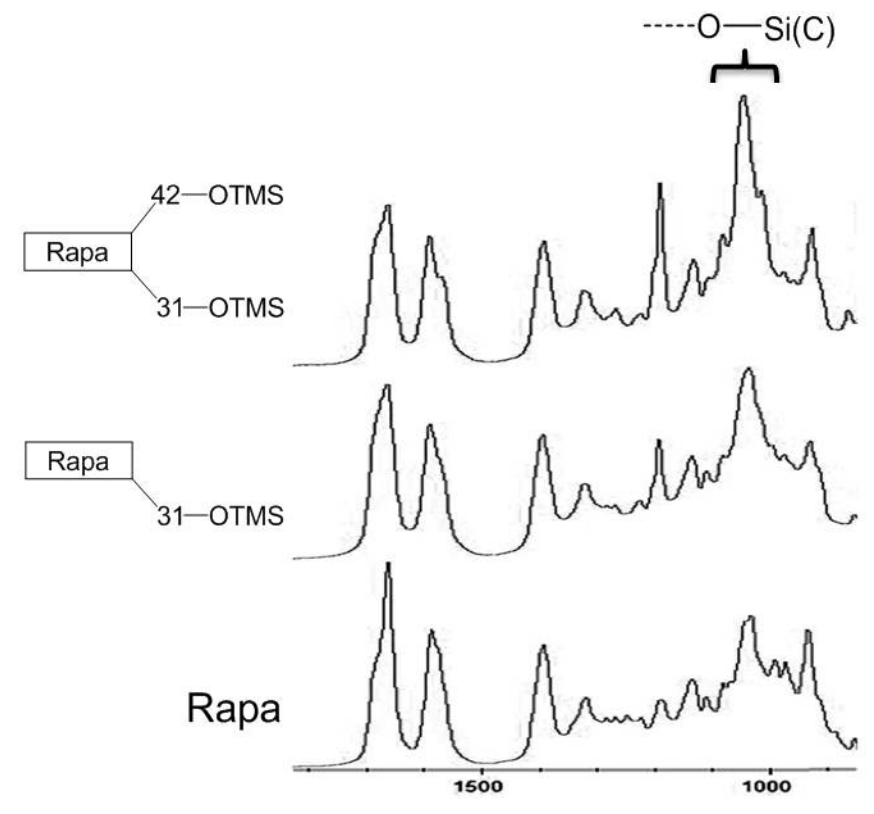

It can be seen from the profile (Figures 3 and 4) that the peak intensity at $1055 \mathrm{~cm}^{-1}$ increases markedly from $\mathbf{a}$ to $\mathbf{b}$, indicating that Rapa is quickly converted to Rapa-31,42-OTMS. After adding $\mathrm{H}_{2} \mathrm{SO}_{4}$ at point $\mathbf{b}$, the peak gradually decreased and then remained stable from $\mathbf{c}$ to $\mathbf{d}$. This result indicates that Rapa-31,42-OTMS is slowly transformed into Rapa-31-OTMS and then the level of Rapa-31-OTMS remains mostly unchanged, while the sharp decrease of the absorption peak from $\mathbf{d}$ to $\mathbf{e}$ indicates that Rapa-31-OTMS begin to convert back to Rapa. The long reaction time and continuously rising acidity lead to the quick hydrolysis of Rapa-31-OTMS after the breakthrough point (d). From the in situ IR data, we concluded that the reaction endpoint lay between $\mathbf{c}$ and $\mathbf{d}$ with a stable yield of $88 \%$ (column separation). In situ IR has the advantages of being highly sensitive, continuous and real-time, which make it more useful than TLC and HPLC, especially for a complicated reaction. This technology could give explicit instructions for process optimization and quality control in the preparation of Rapa-31-OTMS, especially in industrial production. 
Figure 3. 3D FT-IR spectrum fragments for the preparation of Rapa-31-OTMS from Rapa. The reaction was monitored from 0 to $230 \mathrm{~min}$. (a) Addition of TMSCl and imidazole (00:05:00). (b) Addition of $0.5 \mathrm{~N} \mathrm{H}_{2} \mathrm{SO}_{4}$ (00:25:00 to 03:25:00). (a) to (b) Rapa is totally converted to Rapa-31,42-OTMS. (b) to (c) Rapa-31,42-OTMS is mostly converted into Rapa-31-OTMS. (d) to (e): Rapa-31-OTMS is totally converted into Rapa.

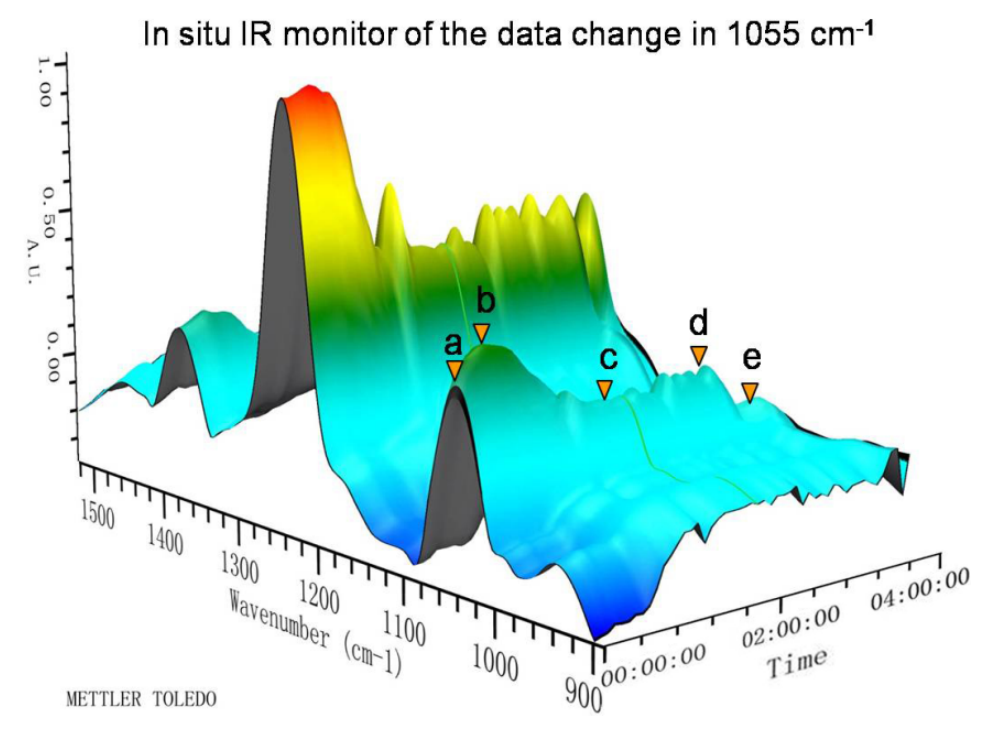

Figure 4. Kinetic profile (peak height $v s$. time) of the intensity of the absorption peak at $1055 \mathrm{~cm}^{-1}$ (the characteristic peak attributed to $-\mathrm{Si}-\mathrm{O}(\mathrm{C})$ ) for the reaction of preparation of Rapa-31-OTMS from Rapa. (a) Addition of TMSCl and imidazole (00:05:00). (b) Addition of $0.5 \mathrm{~N} \mathrm{H}_{2} \mathrm{SO}_{4}$ (00:25:00 to 03:25:00).

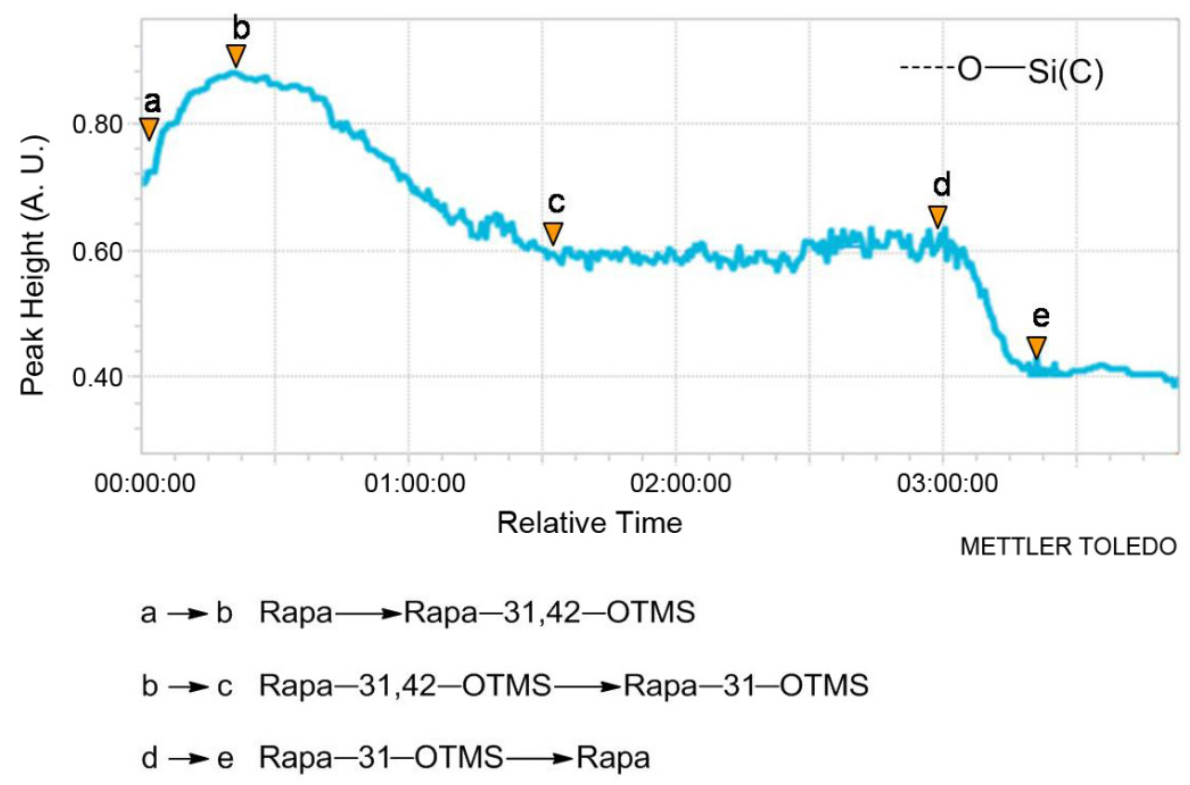

\subsection{Synthesis}

After determining the preparation and control method, the technique was immediately applied in the synthesis of new Rapa derivatives. The choice of substituent groups is another key point to this subject. To avoid the toxicity and side effects produced by metabolism of substituent groups, 
$\mathrm{N}$-(carboxymethyl) thiazolium (or pyridine) derivative side chains were introduced into $31-\mathrm{OH}$ and $42-\mathrm{OH}$ by esterification. The quaternary ammonium salt derivatives developed by our team were nontoxic and showed good water-solubility, and all of them were themselves drugs (AGEs cross-link breakers).

In the paper, the traditional synthesis method was optimized by merging two reactions into one (Scheme 2), so that the reaction steps in the preparation of 42-Rapa derivatives were decreased from 5 to 3 (overall yield $48 \%$ ). The reaction merging strategy could also be implemented in the synthesis of 31-Rapa derivatives, in which the number of steps could be decreased from 7 to 4 (overall yield 15\%). These selective synthesis strategies were achieved by tactfully taking advantage of the subtle differences in reactivity between the two positions, whereby that of the $42-\mathrm{OH}$ is greater than the $31-\mathrm{OH}$, as well as the greater reactivity of the tert-butyldimethylsilyl (TBDMS) ether which is stronger than that of the trimethylsilyl (TMS) ether [14-16]. Smaller steric hindrance may be the main reason for the high reaction activity of the $42-\mathrm{OH}$ position.

Scheme 2. Synthesis routes of 42-Rapa derivatives (a) and 31-Rapa derivatives (b).

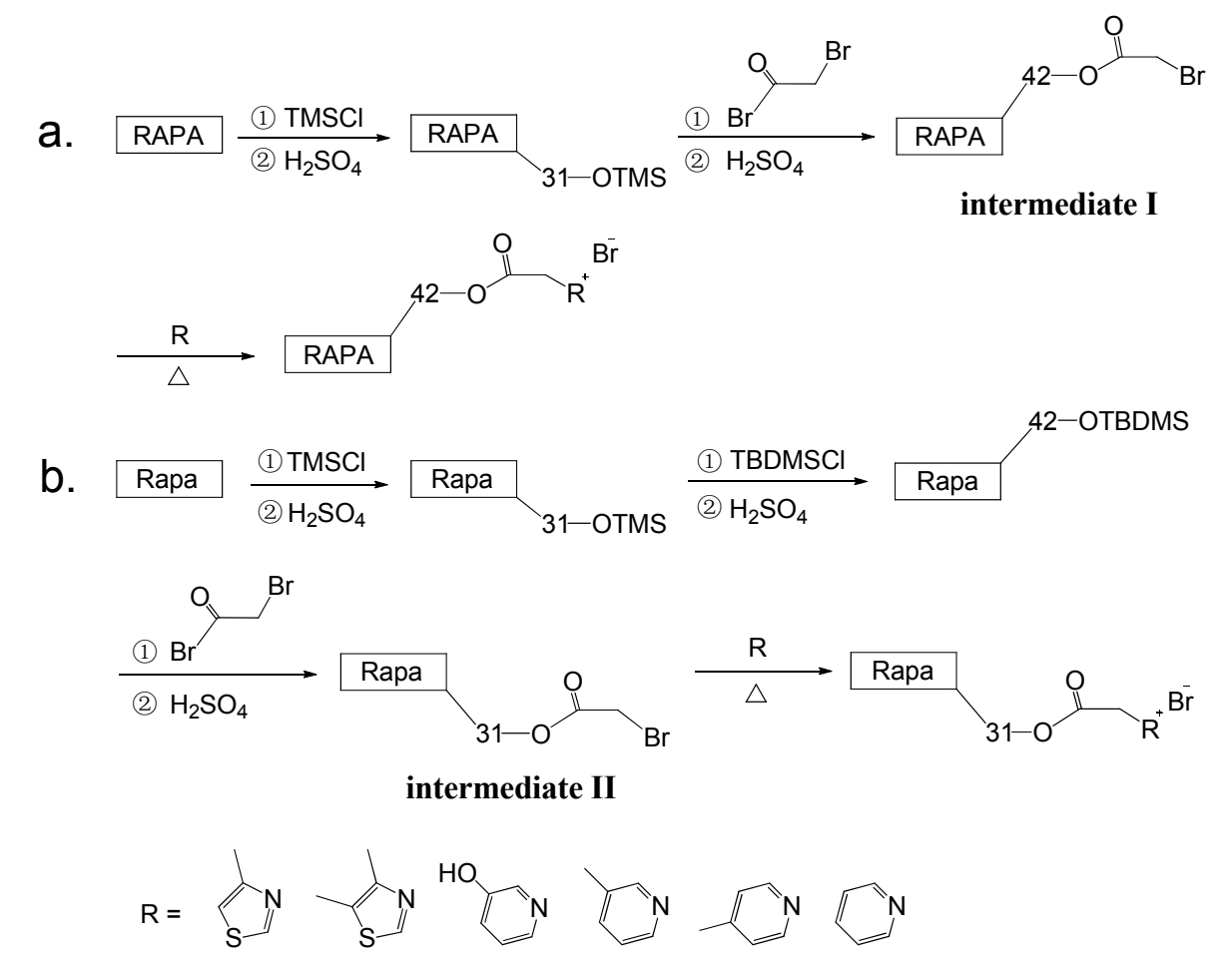

Finally, 11 compounds were produced (Table 1), which were all quaternary ammonium salts. According to the reaction point, these compounds can be classified into two series, 42-Rapa derivatives and 31-Rapa derivatives.

\subsection{Structure}

For these complicated compounds, the determination of the linkage position of the substituent groups is difficult but indispensable. Here, a method for confirming the attachment position and number of substituent groups was developed based on the corresponding NMR spectra.

In order to verify the structures of these 11 derivatives, 2D NMR data including HSQC, HMBC, COSY, TOCSY and ROESY were utilized to assign ${ }^{1} \mathrm{H}$ and ${ }^{13} \mathrm{C}-\mathrm{NMR}$ signals (Supplementary 
Material). For some particular groups, such as the $-\mathrm{OH}$, the combination of hydrogen-deuterium exchange and HMBC technique were used to assign their chemical shifts. Specifically, the 13-OH, 31-OH and 42-OH signals were first located by the hydrogen-deuterium exchange method, and then accurately assigned at 6.44, 5.25 and $4.57 \mathrm{ppm}$ by relevant HMBC correlations, respectively (Table 2). As shown in Figure 5, the three characteristic peaks could serve as markers to locate the position where the substituent group was linked to Rapa.

Table 1. Structures and solubility for compounds 1-11.

(C)


Table 2. ${ }^{1} \mathrm{H}(600 \mathrm{MHz})$ and ${ }^{13} \mathrm{C}(150 \mathrm{MHz})$ NMR chemical shifts $(\delta$, ppm) of Rapa, 1 and 7 in DMSO- $d_{6}$.

\begin{tabular}{|c|c|c|c|c|c|c|}
\hline \multirow{2}{*}{ C } & \multicolumn{2}{|c|}{ Rapa } & \multicolumn{2}{|c|}{ Comp. 1} & \multicolumn{2}{|c|}{ Comp. 7} \\
\hline & $\delta \mathrm{C}$ & $\delta \mathbf{H}$ & $\delta \mathrm{C}$ & $\delta \mathbf{H}$ & $\delta \mathrm{C}$ & $\delta \mathbf{H}$ \\
\hline 1 & 139.26 & 5.46 & 139.28 & 5.46 & 138.73 & 5.46 \\
\hline 2 & 130.38 & 6.15 & 130.37 & 6.15 & 130.64 & 6.12 \\
\hline 3 & 132.28 & 6.22 & 132.33 & 6.22 & 132.23 & 6.25 \\
\hline 4 & 126.99 & 6.37 & 126.94 & 6.37 & 127.18 & 6.37 \\
\hline 5 & 126.94 & 6.11 & 126.87 & 6.11 & 126.94 & 6.20 \\
\hline 6 & 137.81 & - & 137.83 & - & 138.03 & - \\
\hline 7 & 82.22 & 3.61 & 82.19 & 3.61 & 81.91 & 3.63 \\
\hline 8 & 39.91 & $1.24,1.83$ & 39.92 & $1.21,1.83$ & 40.03 & $1.08,1.84$ \\
\hline 9 & 66.18 & 4.01 & 66.17 & 4.06 & 66.00 & 4.03 \\
\hline 10 & 29.60 & $1.80,1.16$ & 29.65 & $1.80,1.17$ & 29.54 & $1.16,1.88$ \\
\hline 11 & 31.08 & $0.83,1.51$ & 30.27 & $0.97,1.61$ & 31.02 & $0.82,1.49$ \\
\hline 12 & 34.76 & 2.01 & 34.77 & 2.01 & 34.57 & 1.99 \\
\hline 13 & 98.97 & - & 98.97 & - & 98.91 & - \\
\hline 13-OH & - & 6.44 & - & 6.49 & - & 6.45 \\
\hline 15 & 198.84 & - & 198.76 & - & 198.21 & - \\
\hline 16 & 166.95 & - & 166.97 & - & 167.00 & - \\
\hline 18 & 43.45 & $3.41,3.15$ & 43.46 & $3.42,3.15$ & 43.67 & $2.99,3.43$ \\
\hline 19 & 24.42 & $1.55,1.26$ & 24.33 & $1.28,1.56$ & 24.41 & $1.28,1.57$ \\
\hline 20 & 20.32 & $1.65,1.38$ & 20.31 & $1.65,1.38$ & 20.40 & $1.43,1.69$ \\
\hline 21 & 26.39 & $2.08,1.56$ & 26.40 & $1.59,2.08$ & 26.27 & $1.60,2.20$ \\
\hline 22 & 50.72 & 4.93 & 50.81 & 4.93 & 51.25 & 4.93 \\
\hline 23 & 169.15 & - & 169.24 & - & 169.46 & - \\
\hline 25 & 73.55 & 4.98 & 73.57 & 4.97 & 73.56 & 4.87 \\
\hline 26 & 39.50 & $2.72,2.37$ & 39.50 & $2.79,2.38$ & 40.03 & $2.34,2.66$ \\
\hline 27 & 207.48 & - & 207.47 & - & 207.03 & - \\
\hline 28 & 45.16 & 3.25 & 45.18 & 3.24 & 45.07 & 3.20 \\
\hline 29 & 124.93 & 5.08 & 124.73 & 5.08 & 124.30 & 4.81 \\
\hline 30 & 137.09 & - & 137.06 & - & 138.03 & - \\
\hline 31-OH & - & 5.25 & - & 5.23 & - & - \\
\hline 31 & 75.70 & 4.01 & 75.77 & 4.06 & 78.51 & 5.35 \\
\hline 32 & 85.52 & 3.94 & 85.41 & 3.97 & 80.89 & 4.54 \\
\hline 33 & 210.47 & - & 210.31 & - & 208.09 & - \\
\hline 34 & 39.37 & 2.39 & 39.36 & 2.43 & 39.92 & 2.48 \\
\hline 35 & 39.22 & $1.39,1.02$ & 39.22 & $1.39,1.02$ & 40.02 & $1.07,1.83$ \\
\hline 36 & 35.15 & 2.20 & 35.11 & 2.22 & 35.05 & 2.24 \\
\hline 37 & 33.34 & 1.66 & 33.27 & 1.67 & 33.57 & 1.59 \\
\hline 38 & 38.36 & $1.03,0.94$ & 37.98 & $0.99,1.06$ & 38.24 & $0.92,0.99$ \\
\hline 39 & 32.50 & 1.23 & 31.81 & 1.35 & 32.42 & 1.22 \\
\hline 40 & 35.41 & $1.88,0.58$ & 34.93 & $2.05,0.73$ & 35.26 & $0.51,1.87$ \\
\hline 41 & 83.71 & 2.81 & 79.85 & 3.15 & 83.68 & 2.76 \\
\hline 42 & 73.55 & 3.15 & 78.14 & 4.67 & 73.15 & 3.10 \\
\hline 42-OH & - & 4.57 & - & - & - & 4.56 \\
\hline 43 & 32.86 & $1.73,1.15$ & 35.11 & $2.01,2.21$ & 32.75 & $1.16,1.74$ \\
\hline 44 & 31.08 & 1.52 & 26.40 & 1.55 & 31.02 & 1.56 \\
\hline
\end{tabular}


Figure 5. Expanded ${ }^{1} \mathrm{H}-\mathrm{NMR}$ spectra (600 MHz, DMSO- $\left.d_{6}\right)$ for compounds Rapa, 1 and 7.

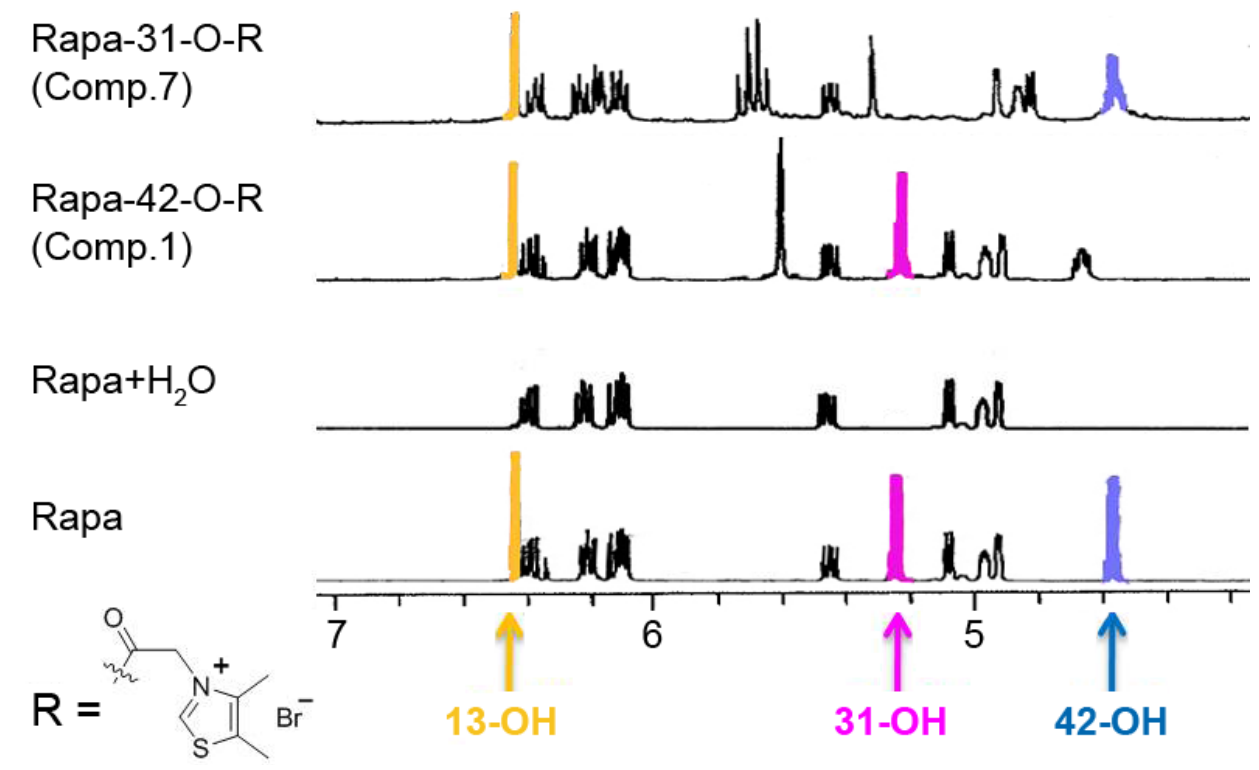

An in-depth analysis of these NMR data revealed more information about the structures. Based on these NMR data (Table 2), a curve was drawn to record the chemical shifts (ppm) of different protons, and the profiles of Rapa, compounds 1 and 7 were put together for comparison (Figure 6). By this way, some structure information was deduced. The chemical shifts of most positions in compounds 1 and 7 are nearly identical, except for those of positions 39 to 44 (region A) and positions 29 to 36 (region B) in three cases (Figure 6). This phenomenon implied that the chemical environments of most of the protons were unchanged, furthermore, we inferred that most of the atoms in compounds $\mathbf{1}$ and 7 maintain a similar chemical environment as those in Rapa. Thus, the change of chemical shifts in region $\mathrm{A}$ and $\mathrm{B}$ could be used to locate the substituents directly.

Figure 6. The curves (chemical shifts $v s$. positions) recording the chemical shifts (ppm) for different positions of protons of Rapa (blue curve), 1 (red curve) and 7 (green curve). Regions A and B were marked by blue and red, respectively.

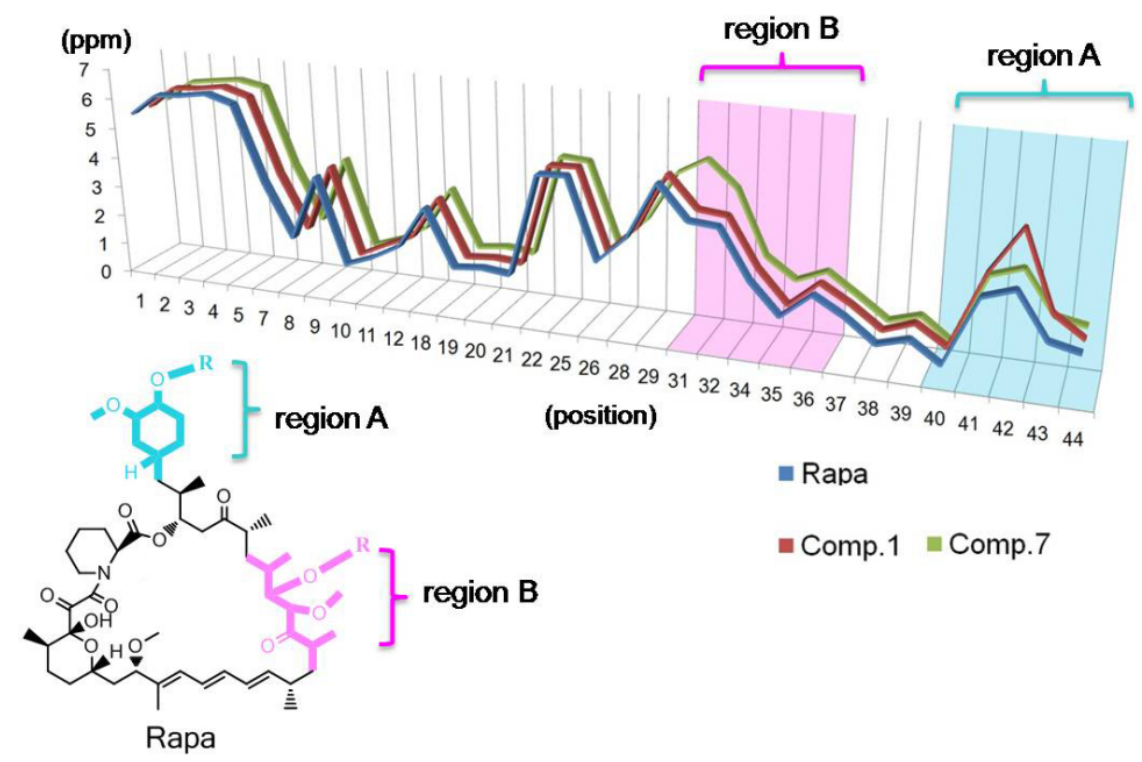


Despite two years of efforts, we had never been able to obtain single crystals of these quaternary ammonium salt derivatives, so we tried to simulate the 3D structure of typical compounds $\mathbf{1}$ and 7. Given the structure of rapamycin was extremely complicated, we attempted to construct this 3D structure based on the X-ray single crystal data of rapamycin reported by Swindel [16-18].

By comparison of the NMR data, we decided to simulate the configuration of region A, region B and the side chain using the molecular modeling software SYBYL 6.5, and at the same time, maintain most of the 3D structure of rapamycin (Figure 7). The accuracy of this simulated 3D structure was confirmed by ROESY NMR experiments. In compound $\mathbf{1}$, the existence of the side chain caused the cyclohexane ring to bend downward, leading to many distinct NOE effects of H41 to H21, H29, H31, $\mathrm{H} 37, \mathrm{H} 38, \mathrm{H} 39$, H40 and H42 (Figure 7a). In compound 7, the molecule folds the side chain in region B placing it very closd to the cyclohexane ring in region A, and this situation could be proved easily by observing the NOE effect between H31c and 42-OH. Moreover, the ROESY correlations between H36 and $\mathrm{H} 29, \mathrm{H} 32, \mathrm{H} 34$ were clearly presented because of the obvious fold in the C26 to C36 region (Figure 7b).

Figure 7. (a) Key partial simulated 3D structure of compound 1 (region A) and key ROESY correlations (red arrows); (b) Key partial simulated 3D structure of compound 7 (region B) and key ROESY correlations (red arrows).

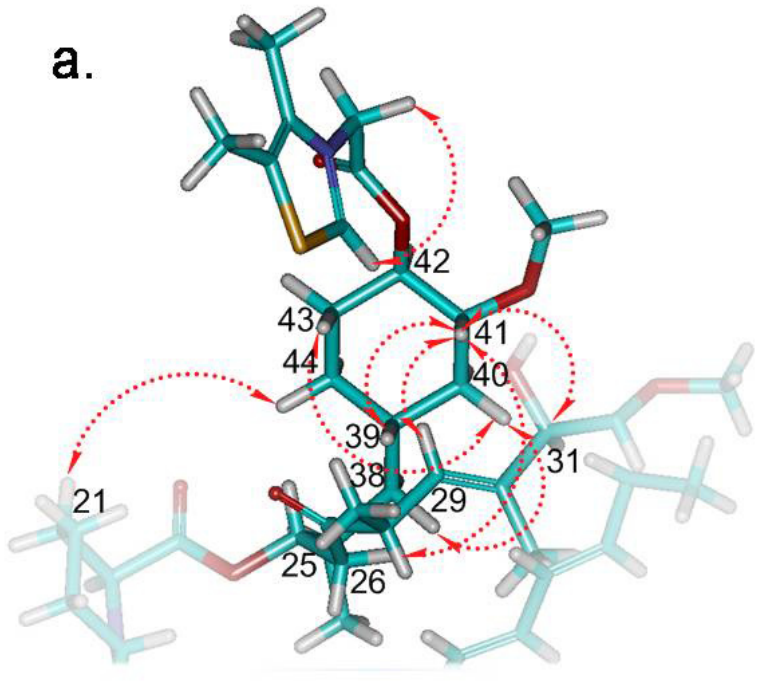

Comp. 1

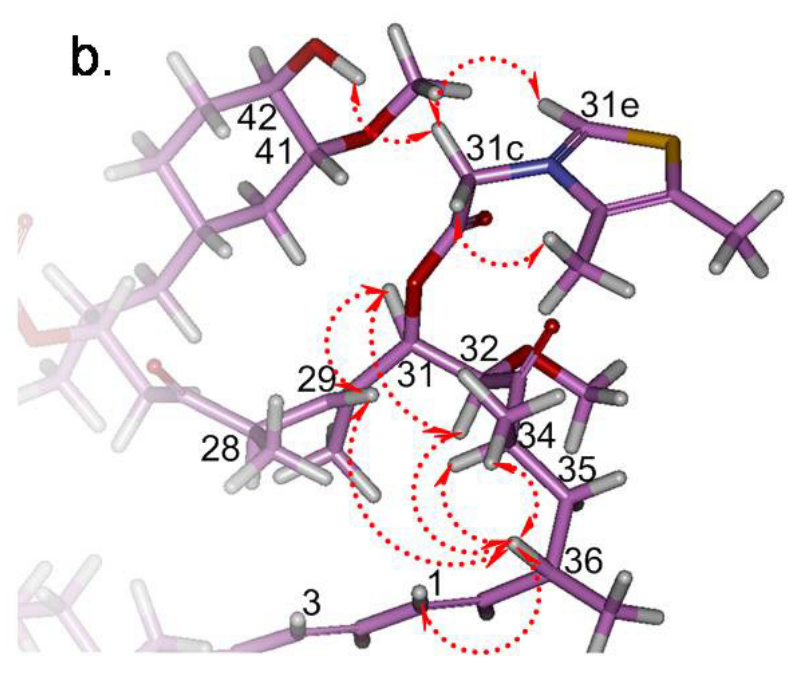

Comp. 7

All the above mentioned results not only proved that the reaction took place at the right positions, but also provided useful information regarding the three dimensional structures of these compounds, which might have a significant value in the field of compound design and structure simulation (Figure 7).

\subsection{Aqueous Solubility}

The aqueous solubility for all 11 compounds was improved remarkably (Table 1), and some (10 and 11) of them were even up to 25,000 times more soluble than Rapa. After summing up the effects of different substituents, a rule about the effect of substitution on aqueous solubility emerged. Generally speaking, the aqueous solubility of 31-Rapa derivatives is obviously superior to that of 42-Rapa derivatives. 


\section{Experimental}

\subsection{Physical Measurements}

Melting points were determined using an RY-1 apparatus. MS spectra were obtained using an Applied Biosystems API-150EX LC/MS mass spectrograph. NMR data was recorded on a Varian Inova $600 \mathrm{MHz}$ spectrometer operating at a proton frequency of $599.6 \mathrm{MHz}$ and a carbon frequency of 150.8 MHz. All NMR spectra were acquired at $27{ }^{\circ} \mathrm{C}$ on a sample of $20 \mathrm{mg}$ of rapamycin derivatives dissolved in $0.2 \mathrm{~mL}$ of DMSO- $d_{6}$, with TMS as an internal standard. 3D-FTIR spectra were obtained from a ReactIR ${ }^{\mathrm{TM}} \mathrm{iC} 10$ instrument equipped with a MCT Detector and a DiComp (Diamond) probe.

\subsection{Synthesis}

\section{Preparation of Rapa-42-ester of 2-(4,5-dimethylthiazolium-3-yl)acetic Acid (1)}

Step 1: Rapa (5 g, $5.5 \mathrm{mmol})$ and imidazole $(3.74 \mathrm{~g}$, $55 \mathrm{mmol})$ were dissolved in ethyl acetate $(50 \mathrm{~mL})$ and the solution was stirred at $0{ }^{\circ} \mathrm{C}$, then a solution of trimethylchlorosilane $(2.98 \mathrm{~g}, 27.5 \mathrm{mmol})$ in ethyl acetate $(5 \mathrm{~mL})$ was added into the reaction solution within $30 \mathrm{~min}$. After the Rapa was transformed into Rapa-31,42-bis-OTMS, dilute sulfuric acid solution $(0.5 \mathrm{~mol} / \mathrm{L}, 10 \mathrm{~mL})$ was slowly added dropwise to the reaction mixture within $3 \mathrm{~h}$. The organic layer was washed three times with water. The organic layer was concentrated and dried over $\mathrm{MgSO}_{4}$. The residue was purified by chromatography on silica gel (EA/PE v/v = 1:5) to obtain Rapa-31-OTMS (4.7 g, 4.8 mmol, yield 88\%).

Step 2: Rapa-31-OTMS (4.7 g, $4.8 \mathrm{mmol})$ and pyridine $(3.7 \mathrm{~g}, 48 \mathrm{mmol})$ were added to dichloromethane at $-10{ }^{\circ} \mathrm{C}$, then, a solution of bromoacetyl bromide $(4.8 \mathrm{~g}, 24 \mathrm{mmol})$ in dichloromethane $(40 \mathrm{~mL})$ was added into the reaction solution within $30 \mathrm{~min}$. The solution was further stirred for $10 \mathrm{~min}$, and warmed to $0-5{ }^{\circ} \mathrm{C}$ in $10 \mathrm{~min}$. Then, dilute sulfuric acid $(1 \mathrm{~mol} / \mathrm{L}, 8 \mathrm{~mL})$ was added to the reaction mixture over $1 \mathrm{~h}$. This mixture was stirred for $30 \mathrm{~min}$. The organic layer was washed three times with water. The combined organic layers were concentrated and dried over $\mathrm{MgSO}_{4}$. The residue was purified by chromatography on silica gel $(\mathrm{EA} / \mathrm{PE} \mathrm{v/v}=1: 8)$ to obtain Rapa-42-ester of bromoacetic acid (intermediate I) (3.82 g, 3.7 mmol, yield 77\%).

Step 3: Intermediate I (3.82 g, $3.7 \mathrm{mmol}$ ) and 4,5-dimethylthiazole (5 equiv., $2.09 \mathrm{~g}, 18.5 \mathrm{mmol}$ ) were added to acetone $(30 \mathrm{~mL})$ at $20^{\circ} \mathrm{C}$, then, the reaction mixture was heated to $60{ }^{\circ} \mathrm{C}$ for $3 \mathrm{~h}$. The solution was concentrated to dryness and the residue was purified by chromatography on silica gel (MeOH/DCM $\mathrm{v} / \mathrm{v}=1: 5)$ to obtain compound 1 (3.61 g, yield 85\%). m.p. $135-138{ }^{\circ} \mathrm{C}$; FTIR $(\mathrm{KBr}): v_{\max } / \mathrm{cm}^{-1}=3422$ $(\mathrm{OH})$ and $2931\left(-\mathrm{CH}_{3}\right), 1723(\mathrm{C}=\mathrm{O}), 1643(\mathrm{C}=\mathrm{O}), 1451,1091$ (-C-O-C-); MS:1067.9 [M-Br] ; ${ }^{+} \mathrm{H}-\mathrm{NMR}$ $(\delta \mathrm{ppm}): 10.03$ (s, 1H, -S-CH=N-), 6.49 (s, 1H, 13-OH), 6.37 (m, 1H, 4-C), $6.21(\mathrm{~m}, 1 \mathrm{H}, 3-\mathrm{C}), 6.14$ (m, 2H, 2-C), $5.62\left(\mathrm{~m}, 2 \mathrm{H},-\mathrm{CH}_{2}-\right), 5.46(\mathrm{~m}, 1 \mathrm{H}, 1-\mathrm{C}), 5.23(\mathrm{~s}, 1 \mathrm{H}, 31-\mathrm{OH}), 5.08(\mathrm{~s}, 1 \mathrm{H}), 4.97(\mathrm{~s}, 1 \mathrm{H}), 4.93$ $(\mathrm{s}, 1 \mathrm{H}), 4.68(\mathrm{~s}, 1 \mathrm{H}), 4.06(\mathrm{~s}, 2 \mathrm{H}), 4.01(\mathrm{~s}, 1 \mathrm{H}) .{ }^{13} \mathrm{C}-\mathrm{NMR}(\delta \mathrm{ppm}): 210.31,207.47,198.76,169.24$, 158.14, 141.91, 138.28, 130.37, 98.97. Anal. calcd for $\mathrm{C}_{58} \mathrm{H}_{87} \mathrm{~N}_{2} \mathrm{O}_{14} \mathrm{SBr}$ : C 60.67, H 7.64, N 2.44, Br 6.96\%. Found: C 60.49, H 7.66, N 2.45, Br 6.93\%. 
Rapa-42-ester of 2-(4-methylthiazolium-3-yl)acetic Acid (2). The procedure described above for the preparation of compound $\mathbf{1}$ was applied to intermediate $\mathbf{I}$ and 4-methylthiazole to afford the title compound 2 (yield 89\%). m.p. $130-133{ }^{\circ} \mathrm{C}$; FTIR $(\mathrm{KBr}): v_{\max } / \mathrm{cm}^{-1}=3422(\mathrm{OH})$ and $2933\left(-\mathrm{CH}_{3}\right)$, $1720(\mathrm{C}=\mathrm{O}), 1643(\mathrm{C}=\mathrm{O}), 1451,1103$ (-C-O-C-); MS:1053.8 [M-Br] ${ }^{+}$; ${ }^{1} \mathrm{H}-\mathrm{NMR}(\delta \mathrm{ppm}): 10.16(\mathrm{~d}, 1 \mathrm{H}$, $-\mathrm{S}-\mathrm{CH}=\mathrm{N}-), 8.06$ (s, 1H, -S-CH=), $6.45(\mathrm{~s}, 1 \mathrm{H}, 13-\mathrm{OH}), 6.38(\mathrm{~m}, 1 \mathrm{H}, 4-\mathrm{C}), 6.22(\mathrm{~m}, 1 \mathrm{H}, 3-\mathrm{C}), 6.15$ (m, $1 \mathrm{H}, 2-\mathrm{C}), 5.62\left(\mathrm{~s}, 2 \mathrm{H},-\mathrm{CH}_{2}-\right), 5.46(\mathrm{~m}, 1 \mathrm{H}, 1-\mathrm{C}), 5.24(\mathrm{~s}, 1 \mathrm{H}, 31-\mathrm{OH}), 5.08(\mathrm{~d}, 1 \mathrm{H}), 4.97(\mathrm{~s}, 1 \mathrm{H}), 4.93$ $(\mathrm{s}, 1 \mathrm{H}), 4.68(\mathrm{~m}, 1 \mathrm{H}), 4.00(\mathrm{~s}, 2 \mathrm{H}), 3.97(\mathrm{~s}, 1 \mathrm{H}) .{ }^{13} \mathrm{C}-\mathrm{NMR}(\delta \mathrm{ppm}): 214.58,178.64,169.24,164.76$, 146.53, 120.99, 98.40, 67.14. Anal. calcd for $\mathrm{C}_{57} \mathrm{H}_{85} \mathrm{~N}_{2} \mathrm{O}_{14} \mathrm{SBr}$ : C 60.36, H 7.55, N 2.47, Br 7.04\%. Found: C 60.28, H 7.57, N 2.48, Br 7.00\%. (89\% yield).

Rapa-42-ester of 2-(pyridinium-1-yl)acetic Acid (3). The procedure described above for the preparation of compound $\mathbf{1}$ was applied to intermediate $\mathbf{I}$ and pyridine to afford the title compound $\mathbf{3}$ (yield 87\%). m.p. $135-137{ }^{\circ} \mathrm{C}$; FTIR (KBr): $v_{\max } / \mathrm{cm}^{-1}=3408(\mathrm{OH})$ and $2934\left(-\mathrm{CH}_{3}\right), 1738(\mathrm{C}=\mathrm{O}), 1638(\mathrm{C}=\mathrm{O})$, 1452, 1104 (-C-O-C-); MS:1034.1 [M-Br] ${ }^{+}$; ${ }^{1} \mathrm{H}-\mathrm{NMR}(\delta \mathrm{ppm}): 9.07$ (d, 1H, pyridine), $9.02(\mathrm{~m}, 1 \mathrm{H}$, pyridine), $8.71(\mathrm{~m}, 1 \mathrm{H}$, pyridine), $8.24(\mathrm{~m}, 2 \mathrm{H}$, pyridine $), 6.45(\mathrm{~s}, 1 \mathrm{H}, 13-\mathrm{OH}), 6.41(\mathrm{~m}, 1 \mathrm{H}, 4-\mathrm{C}), 6.22$ $(\mathrm{m}, 1 \mathrm{H}, 3-\mathrm{C}), 6.14(\mathrm{~m}, 1 \mathrm{H}, 2-\mathrm{C}), 5.80(\mathrm{~m}, 5 \mathrm{H}), 5.67\left(\mathrm{~m}, 2 \mathrm{H},-\mathrm{CH}_{2^{-}}\right), 5.44(\mathrm{~m}, 1 \mathrm{H}), 5.25(\mathrm{~s}, 1 \mathrm{H}$, 31-OH), 5.08 (m, 1H). ${ }^{13} \mathrm{C}-\mathrm{NMR}(\delta \mathrm{ppm}): 211.92,208.23,193.37,169.24,160.10,145.63,139.71$, 130.17, 98.46. Anal. calcd for $\mathrm{C}_{58} \mathrm{H}_{85} \mathrm{~N}_{2} \mathrm{O}_{14} \mathrm{Br}$ : C 62.52, H 7.69, N 2.51, Br 7.17\%. Found: C 62.44, H 7.71, N 2.53, Br 7.13\%.

Rapa-42-ester of 2-(3-methylpyridinium-1-yl)acetic Acid (4). The procedure described above for the preparation of compound $\mathbf{1}$ was applied to intermediate $\mathbf{I}$ and 3-methylpyridine to afford the title compound 4 (yield 82\%). m.p. $138-140{ }^{\circ} \mathrm{C}$; MS:1048 [M-Br] ${ }^{+}$; FTIR $(\mathrm{KBr}): v_{\max } / \mathrm{cm}^{-1}=3422(\mathrm{OH})$ and $2933\left(-\mathrm{CH}_{3}\right), 1742(\mathrm{C}=\mathrm{O}), 1641(\mathrm{C}=\mathrm{O}), 1452,1103$ (-C-O-C-); ${ }^{1} \mathrm{H}-\mathrm{NMR}(\delta \mathrm{ppm}): 9.07(\mathrm{~d}, 1 \mathrm{H}$, pyridine $), 9.02(\mathrm{~m}, 1 \mathrm{H}$, pyridine $), 8.71(\mathrm{~m}, 1 \mathrm{H}$, pyridine $), 8.14(\mathrm{~m}, 2 \mathrm{H}$, pyridine $), 6.45(\mathrm{~s}, 1 \mathrm{H}, 13-\mathrm{OH})$, $6.41(\mathrm{~m}, 1 \mathrm{H}, 4-\mathrm{C}), 6.22(\mathrm{~m}, 1 \mathrm{H}, 3-\mathrm{C}), 6.14(\mathrm{~m}, 1 \mathrm{H}, 2-\mathrm{C}), 5.80(\mathrm{~m}, 5 \mathrm{H}), 5.67(\mathrm{~m}, 2 \mathrm{H}), 5.44(\mathrm{~m}, 1 \mathrm{H})$, $5.25(\mathrm{~s}, 1 \mathrm{H}, 31-\mathrm{OH}), 5.08(\mathrm{~m}, 1 \mathrm{H}) .{ }^{13} \mathrm{C}-\mathrm{NMR}(\delta \mathrm{ppm}) 214.60,208.32,169.25,166.67,165.55$, 139.01, 98.41, 80.42. Anal. calcd for $\mathrm{C}_{59} \mathrm{H}_{87} \mathrm{~N}_{2} \mathrm{O}_{14} \mathrm{Br}$ : C 62.81, H 7.77, N 2.48, Br 7.08\%. Found: C 62.80, H 7.79, N 2.49, Br 7.05\%.

Rapa-42-ester of 2-(3-hydroxypyridinium-1-yl)acetic Acid (5). The procedure described above for the preparation of compound $\mathbf{1}$ was applied intermediate $\mathbf{I}$ and 3-hydroxypyridine to afford the title compound 5 (yield 80\%). m.p. 146-148 ${ }^{\circ} \mathrm{C}$; FTIR $(\mathrm{KBr}): v_{\max } / \mathrm{cm}^{-1}=3426(\mathrm{OH})$ and $2933\left(-\mathrm{CH}_{3}\right)$, $1721(\mathrm{C}=\mathrm{O}), 1641(\mathrm{C}=\mathrm{O}), 1452,1102(-\mathrm{C}-\mathrm{O}-\mathrm{C}-)$; MS:1050 [M-Br] $]^{+} ;{ }^{1} \mathrm{H}-\mathrm{NMR}(\delta \mathrm{ppm}): 12.08(\mathrm{~s}, 1 \mathrm{H}$, pyridine- $\mathrm{OH}), 8.60(\mathrm{~m}, 1 \mathrm{H}$, pyridine), $8.53(\mathrm{~m}, 1 \mathrm{H}$, pyridine $), 8.02(\mathrm{~m}, 2 \mathrm{H}$, pyridine), $6.45(\mathrm{~m}, 2 \mathrm{H}$, 13-OH), 6.38 (s, 1H, 4-C), 6.22 (m, 1H, 3-C), 6.12 (m, 2H, 2-C), 5.60 (m, 2H), 5.48 (m, 1H), 5.25 (s, $1 \mathrm{H}, 31-\mathrm{OH}), 5.08(\mathrm{~m}, 1 \mathrm{H}) .{ }^{13} \mathrm{C}-\mathrm{NMR}(\delta \mathrm{ppm}): 214.41,208.35,169.29,166.66,164.97,157.62$, 139.53, 133.25, 98.43. Anal. calcd for $\mathrm{C}_{58} \mathrm{H}_{85} \mathrm{~N}_{2} \mathrm{O}_{14} \mathrm{Br}$ : C 61.64, H 7.58, N 2.48, Br 7.07\%. Found: C 61.56, H 7.60, N 2.49, Br 7.04\%.

Rapa-42-ester of 2-(4-methylpyridinium-1-yl)acetic Acid (6). The procedure described above for the preparation of compound $\mathbf{1}$ was applied to intermediate $\mathbf{I}$ and 4-methylpyridine to afford the title compound 6 (yield 84\%). m.p. $157-160{ }^{\circ} \mathrm{C}$; FTIR $(\mathrm{KBr}): v_{\max } / \mathrm{cm}^{-1}=3425(\mathrm{OH})$ and $2933\left(-\mathrm{CH}_{3}\right)$, 
$1742(\mathrm{C}=\mathrm{O}), 1643(\mathrm{C}=\mathrm{O}), 1452,1102$ (-C-O-C-); MS:1048.1 [M-Br] ; ${ }^{1} \mathrm{H}-\mathrm{NMR}(\delta \mathrm{ppm}): 8.89$ (d, 1H, pyridine), $8.05(\mathrm{~m}, 2 \mathrm{H}$, pyridine), $6.45(\mathrm{~s}, 1 \mathrm{H}, 13-\mathrm{OH}), 6.41(\mathrm{~m}, 1 \mathrm{H}, 4-\mathrm{C}), 6.22(\mathrm{~m}, 1 \mathrm{H}, 3-\mathrm{C}), 6.12(\mathrm{~m}, 2 \mathrm{H}$, 2-C), $5.61(\mathrm{~m}, 3 \mathrm{H}), 5.46(\mathrm{~m}, 1 \mathrm{H}), 5.25(\mathrm{~m}, 1 \mathrm{H}, 31-\mathrm{OH}), 5.08(\mathrm{~d}, 1 \mathrm{H}), 4.93(\mathrm{~m}, 2 \mathrm{H}) .{ }^{13} \mathrm{C}-\mathrm{NMR}(\delta \mathrm{ppm})$ : 214.65, 208.23, 192.96, 169.26, 160.09, 145.61, 139.70, 130.17, 98.46. Anal. calcd for $\mathrm{C}_{59} \mathrm{H}_{87} \mathrm{~N}_{2} \mathrm{O}_{14} \mathrm{Br}$ : C 62.81, H 7.77, N 2.48, Br 7.08\%. Found: C 62.73, H 7.80, N 2.49, Br 7.05\%.

Preparation of Rapa-31-ester of 2-(4,5-dimethylthiazolium-3-yl)acetic Acid (7)

Step 1: Rapa (5 g, $5.5 \mathrm{mmol})$ and imidazole $(3.74 \mathrm{~g}$, $55 \mathrm{mmol})$ were dissolved in ethyl acetate $(50 \mathrm{~mL})$ and the solution was stirred at $0{ }^{\circ} \mathrm{C}$, then a solution of trimethylchlorosilane $(2.98 \mathrm{~g}, 27.5 \mathrm{mmol})$ in ethyl acetate $(5 \mathrm{~mL})$ was added into the reaction solution within $30 \mathrm{~min}$. After the Rapa was transformed into Rapa-31,42-bis-OTMS, dilute sulfuric acid $(0.5 \mathrm{~mol} / \mathrm{L}, 10 \mathrm{~mL})$ solution was slowly added dropwise into the reaction mixture within $3 \mathrm{~h}$. The organic layer was washed three times with water. The organic layer was concentrated and dried over $\mathrm{MgSO}_{4}$. The residue was purified by chromatography on silica gel (EA/PE v/v = 1:5) to obtain Rapa-31-OTMS (4.6 g, 4.7 mmol, yield 88\%).

Step 2: To a mixture of Rapa-31-OTMS (4.6 g, $4.7 \mathrm{mmol})$ and imidazole (3.3 g, $48 \mathrm{mmol})$ in ethyl acetate $(40 \mathrm{~mL})$ at $0{ }^{\circ} \mathrm{C}$, a solution of tert-butyldimethylsilylchlide (TBDMSCl) $(3.54 \mathrm{~g}, 24 \mathrm{mmol})$ in ethyl acetate $(10 \mathrm{~mL})$ was added within $30 \mathrm{~min}$. After all the reagent was transformed into Rapa-31-OTMS-42-OTBDMS, dilute sulfuric acid $(0.5 \mathrm{~mol} / \mathrm{L}, 8 \mathrm{~mL})$ was added into the solution within $1 \mathrm{~h}$. The reaction solution was washed with water three times and the organic layer was concentrated and dried over $\mathrm{MgSO}_{4}$. The residue was purified by chromatography on silica gel (EA/PE $\mathrm{v} / \mathrm{v}=1: 5)$ to obtain Rapa-42-OTBDMS (2.41 g, $2.4 \mathrm{mmol}$, yield 50\%).

Step 3: Rapa-42-OTBDMS (2.41 g, $2.4 \mathrm{mmol})$ and pyridine (1.89 g, $24 \mathrm{mmol})$ were added into acetone $(50 \mathrm{~mL})$ at $-10^{\circ} \mathrm{C}$. A solution of bromoacetyl bromide (5 equiv) in acetone $(5 \mathrm{~mL})$ was added into this mixture within $30 \mathrm{~min}$ and further stirred for $10 \mathrm{~min}$. Then, the reaction was heated to $0-5{ }^{\circ} \mathrm{C}$ in $10 \mathrm{~min}$, and dilute sulfuric acid $(2 \mathrm{~mol} / \mathrm{L}, 5 \mathrm{~mL})$ was added into the solution in $30 \mathrm{~min}$. The solution was concentrated to dryness and the residue was purified by chromatography on silica gel (EA/PE $\mathrm{v} / \mathrm{v}=1: 8)$ to obtain Rapa-31-ester of bromoacetic acid (intermediate II) (0.94 g, 0.9 mmol, yield 38\%).

Step 4: Intermediate II (0.94 g, $0.9 \mathrm{mmol})$ and 4,5-dimethylthiazole (5 equiv., $0.51 \mathrm{~g}, 4.5 \mathrm{mmol})$ were added to acetone $(10 \mathrm{~mL})$ at $20^{\circ} \mathrm{C}$, then, the reaction mixture was heated to $60{ }^{\circ} \mathrm{C}$ for $3 \mathrm{~h}$. The solution was concentrated to dryness and the residue was purified by chromatography on silica gel $(\mathrm{MeOH} / \mathrm{DCM} \mathrm{v} / \mathrm{v}=1: 5)$ to obtain compound 7 (0.72 g, $0.63 \mathrm{mmol}$, yield 70\%). m.p. $125-127{ }^{\circ} \mathrm{C}$; FTIR (KBr): $v_{\max } / \mathrm{cm}^{-1}=3421(\mathrm{OH})$ and $2933\left(-\mathrm{CH}_{3}\right), 1720(\mathrm{C}=\mathrm{O}), 1643(\mathrm{C}=\mathrm{O}), 1452,1104(-\mathrm{C}-\mathrm{O}-\mathrm{C}-)$; MS:1067.7 [M-Br] ; ${ }^{+} \mathrm{H}-\mathrm{NMR}(\delta \mathrm{ppm}): 10.02(\mathrm{~d}, 1 \mathrm{H},-\mathrm{S}-\mathrm{CH}=\mathrm{N}-), 6.45(\mathrm{~s}, 1 \mathrm{H}, 13-\mathrm{OH}), 6.37$ (m, 1H, 4-C), $6.25(\mathrm{~m}, 1 \mathrm{H}, 3-\mathrm{C}), 6.20(\mathrm{~m}, 1 \mathrm{H}, 5-\mathrm{C}), 6.15(\mathrm{~m}, 1 \mathrm{H}, 2-\mathrm{C}), 5.70(\mathrm{~m}, 2 \mathrm{H}), 5.45(\mathrm{~m}, 1 \mathrm{H}), 5.33(\mathrm{~s}, 1 \mathrm{H})$, $5.08(\mathrm{~s}, 1 \mathrm{H}), 4.93(\mathrm{~s}, 1 \mathrm{H}), 4.81(\mathrm{~m}, 1 \mathrm{H}), 4.56(\mathrm{~m}, 3 \mathrm{H}, 42-\mathrm{OH}) .{ }^{13} \mathrm{C}-\mathrm{NMR}(\delta \mathrm{ppm}): 208.09,207.03$, 198.21, 169.46, 157.92, 142.01, 138.03, 130.64, 98.91. Anal. calcd for $\mathrm{C}_{58} \mathrm{H}_{87} \mathrm{~N}_{2} \mathrm{O}_{14} \mathrm{SBr}$ : C 60.67, H 7.64, N 2.44, Br 6.96\%. Found: C 60.53, H 7.65, N 2.46, Br 6.93\%.

Rapa-31-ester of 2-(4-methylthiazolium-3-yl)acetic Acid (8). The procedure described above for the preparation of compound 7 was applied to intermediate II and 4-methylthiazole to afford the title 
compound 8 (yield 62\%). m.p. $130-132{ }^{\circ} \mathrm{C}$; FTIR $(\mathrm{KBr}): v_{\max } / \mathrm{cm}^{-1}=3420(\mathrm{OH})$ and $2932\left(-\mathrm{CH}_{3}\right)$, $1746(\mathrm{C}=\mathrm{O}), 1642(\mathrm{C}=\mathrm{O}), 1452,1106$ (-C-O-C-); MS:1054 [M-Br] $]^{+} ;{ }^{1} \mathrm{H}-\mathrm{NMR}(\delta \mathrm{ppm}): 10.16(\mathrm{~d}, 1 \mathrm{H}$, $-\mathrm{S}-\mathrm{CH}=\mathrm{N}-), 8.05$ (s, 1H, S-CH=C), 6.45 (s, 1H, 13-OH), 6.37 (m, 1H, 4-C), 6.25 (m, 1H, 3-C), 6.18 $(\mathrm{m}, 1 \mathrm{H}, 5-\mathrm{C}), 5.70(\mathrm{~s}, 2 \mathrm{H}), 5.46(\mathrm{~m}, 1 \mathrm{H}), 5.35(\mathrm{~s}, 1 \mathrm{H}), 4.55(\mathrm{~d}, 2 \mathrm{H}, 42-\mathrm{OH}) .{ }^{13} \mathrm{C}-\mathrm{NMR}(\delta \mathrm{ppm})$ : 214.58, 178.64, 169.24, 164.76, 146.53, 120.99, 98.40, 67.14. Anal. calcd for $\mathrm{C}_{57} \mathrm{H}_{85} \mathrm{~N}_{2} \mathrm{O}_{14} \mathrm{SBr}$ : C 60.36, H 7.55, N 2.47, Br 7.04\%. Found: C 60.28, H 7.57, N 2.48, Br 7.00\%.

Rapa-31-ester of 2-(3-methylpyridinium-1-yl)acetic Acid (9). The procedure described above for the preparation of compound 7 was applied to intermediate II and 3-methylpyridine to afford the title compound 9 (yield 82\%). m.p. $138-140{ }^{\circ} \mathrm{C}$; FTIR $(\mathrm{KBr}): v_{\max } / \mathrm{cm}^{-1}=3424(\mathrm{OH})$ and $2932\left(-\mathrm{CH}_{3}\right)$, $1723(\mathrm{C}=\mathrm{O}), 1641(\mathrm{C}=\mathrm{O}), 1452,1190(-\mathrm{C}-\mathrm{O}-\mathrm{C}-)$; MS:1048.1 [M-Br] ${ }^{+} ;{ }^{1} \mathrm{H}-\mathrm{NMR}(\delta \mathrm{ppm}): 8.88(\mathrm{~d}, 1 \mathrm{H}$, pyridine), $8.80(\mathrm{~d}, 1 \mathrm{H}$, pyridine), $8.57(\mathrm{~m}, 1 \mathrm{H}$, pyridine $), 8.12(\mathrm{~m}, 1 \mathrm{H}$, pyridine $), 6.45(\mathrm{~m}, 1 \mathrm{H}, 13-\mathrm{OH})$, $6.40(\mathrm{~m}, 1 \mathrm{H}, 4-\mathrm{C}), 6.23(\mathrm{~m}, 1 \mathrm{H}, 3-\mathrm{C}), 6.17(\mathrm{~m}, 1 \mathrm{H}, 5-\mathrm{C}), 5.81(\mathrm{~d}, 1 \mathrm{H}), 5.74(\mathrm{~m}, 2 \mathrm{H}), 5.47(\mathrm{~m}, 1 \mathrm{H})$, $5.28(\mathrm{~s}, 1 \mathrm{H}), 4.58(\mathrm{~s}, 1 \mathrm{H}, 42-\mathrm{OH}) .{ }^{13} \mathrm{C}-\mathrm{NMR}(\delta \mathrm{ppm}): 212.91,208.19,169.30,166.92,164.60$, 143.79, 139.41, 130.17, 98.29. Anal. calcd for $\mathrm{C}_{59} \mathrm{H}_{87} \mathrm{~N}_{2} \mathrm{O}_{14} \mathrm{Br}$ : C 62.81, H 7.77, N 2.48, Br 7.08\%. Found: C 62.73, H 7.79, N 2.50, Br 7.04\%.

Rapa-31-ester of 2-(pyridinium-1-yl)acetic Acid (10). The procedure described above for the preparation of compound $\mathbf{7}$ was applied to intermediate II and pyridine to afford the title compound $\mathbf{1 0}$ (yield 59\%). m.p. $140-142{ }^{\circ} \mathrm{C}$; FTIR (KBr): $v_{\max } / \mathrm{cm}^{-1}=3425(\mathrm{OH})$ and $2932\left(-\mathrm{CH}_{3}\right), 1723(\mathrm{C}=\mathrm{O}), 1640$ $(\mathrm{C}=\mathrm{O}), 1452,1092$ (-C-O-C-); MS: $1034[\mathrm{M}-\mathrm{Br}]^{+}$; ${ }^{1} \mathrm{H}-\mathrm{NMR}(\delta \mathrm{ppm}): 8.96(\mathrm{~d}, 2 \mathrm{H}$, pyridine $), 8.72(\mathrm{~m}$, $1 \mathrm{H}$, pyridine), 8.22 (m, 2H, pyridine), $6.44(\mathrm{~s}, 1 \mathrm{H}, 13-\mathrm{OH}), 6.40(\mathrm{~m}, 1 \mathrm{H}, 4-\mathrm{C}), 6.24(\mathrm{~m}, 1 \mathrm{H}, 3-\mathrm{C}), 6.17$ $(\mathrm{m}, 2 \mathrm{H}, 5-\mathrm{C}), 5.87(\mathrm{~m}, 1 \mathrm{H}), 5.79(\mathrm{~m}, 1 \mathrm{H}), 5.48(\mathrm{~m}, 1 \mathrm{H}), 5.29(\mathrm{~s}, 1 \mathrm{H}), 4.95(\mathrm{~m}, 2 \mathrm{H}), 4.81(\mathrm{~s}, 1 \mathrm{H}), 4.52$ $(\mathrm{s}, 1 \mathrm{H}, 42-\mathrm{OH}) .{ }^{13} \mathrm{C}-\mathrm{NMR}(\delta \mathrm{ppm}): 208.14,169.29,166.94,146.65,140.02,126.43,98.29$. Anal. calcd for $\mathrm{C}_{58} \mathrm{H}_{85} \mathrm{~N}_{2} \mathrm{O}_{14} \mathrm{Br}$ : C 62.52, H 7.69, N 2.51, Br 7.17\%. Found: C 62.44, H 7.71, N 2.52, Br 7.14\%.

Rapa-31-ester of 2-(4-methylpyridinium-1-yl)acetic Acid (11). The procedure described above for the preparation of compound 7 was applied to intermediate II and 4-methylpyridine to afford the title compound 11 (yield 65\%). m.p. $145-148{ }^{\circ} \mathrm{C}$; FTIR (KBr): $v_{\max } / \mathrm{cm}^{-1}=3424(\mathrm{OH})$ and $2932\left(-\mathrm{CH}_{3}\right)$, $1723(\mathrm{C}=\mathrm{O}), 1644(\mathrm{C}=\mathrm{O}), 1452,1092(-\mathrm{C}-\mathrm{O}-\mathrm{C}-)$; MS:1048.1 [M-Br] ${ }^{+} ;{ }^{1} \mathrm{H}-\mathrm{NMR}(\delta \mathrm{ppm}): 8.77(\mathrm{~d}, 2 \mathrm{H}$, pyridine), $8.03(\mathrm{~d}, 2 \mathrm{H}$, pyridine), $6.44(\mathrm{~s}, 1 \mathrm{H}, 13-\mathrm{OH}), 6.40(\mathrm{~m}, 1 \mathrm{H}, 4-\mathrm{C}), 6.23(\mathrm{~m}, 1 \mathrm{H}, 3-\mathrm{C}), 6.16(\mathrm{~m}$, 2H, 5-C), $5.80(\mathrm{~d}, 1 \mathrm{H}), 5.70(\mathrm{~d}, 1 \mathrm{H}), 5.44(\mathrm{~m}, 1 \mathrm{H}), 5.29(\mathrm{~m}, 1 \mathrm{H}), 5.29(\mathrm{~s}, 1 \mathrm{H}), 4.52(\mathrm{~s}, 1 \mathrm{H}, 42-\mathrm{OH})$. ${ }^{13} \mathrm{C}-\mathrm{NMR}(\delta \mathrm{ppm}): 212.72,169.35,164.95,160.41,145.50,139.79,129.23,98.17,84.23$. Anal. calcd for $\mathrm{C}_{59} \mathrm{H}_{87} \mathrm{~N}_{2} \mathrm{O}_{14} \mathrm{Br}$ : C 62.81, H 7.77, N 2.48, Br 7.08\%. Found: C 62.67, H 7.79, N 2.49, Br 7.05\%.

\section{Conclusions}

The in situ IR technique was successfully applied in the selective synthesis of the key intermediate for preparing Rapa derivatives, which made the determination of the reaction endpoint easier so as to make the reaction high yield $(88 \%)$ and controllable. In total 11 mono-substituted Rapa derivatives (six 42-Rapa derivatives and five 31-Rapa derivatives) were synthesized, and all of them had a quaternary ammonium salt structures. The aqueous solubility of all these compounds was obviously improved. Among them, the aqueous solubility of compounds $\mathbf{1 0}$ and $\mathbf{1 1}$ jumped to $62 \mathrm{mg} / \mathrm{mL}$, nearly 
25,000 times that of Rapa. The spatial configuration of these Rapa derivatives was simulated by the molecular modeling software SYBYL 6.5, which showed a good agreement with the 2D NMR data. This provides valuable information to guide further compound design and synthesis.

\section{Supplementary Materials}

Supplementary materials can be accessed at: http://www.mdpi.com/1420-3049/19/6/7770/s1.

\section{Acknowledgments}

This work was supported by the Program for Innovative Research Team of the Ministry of Education and Program for Liaoning Innovative Research Team in University, and by Grant No. 2011BAI18B01 to Wu Zhong from the National Key Technology R \& D Program.

\section{Author Contributions}

Shuang Cao, Wu Zhong and Tiemin Sun designed research; Shuang Cao, Xinbo Zhou and Yuanshuai Yang performed research and analyzed the data; Shuang Cao wrote the paper. All authors read and approved the final manuscript.

\section{Conflicts of Interest}

The authors declare no conflict of interest.

\section{References}

1. Gomez-Pinillos, A.; Ferrari, A.C. mTOR signaling pathway and mTOR inhibitors in Cancer therapy. Hematol. Oncol. Clin. N. 2012, 26, 483-505.

2. Zhou, H.Y.; Huang, S.L. Current development of the second generation of mTOR inhibitors as anticancer agents. Chin. J. Cancer 2012, 31, 8-18.

3. Lv, X.; Ma, X.; Hu, Y. Furthering the design and the discovery of small molecule ATP-competitive mTOR inhibitors as an effective cancer treatment. Expert Opin. Drug Discov. 2013, 8, 991-1012.

4. Laplante, M.; Sabatini, D.M. mTOR signaling in growth control and disease. Cell 2012, 149, 274-293.

5. Simamora, P.; Alvarez, J.M.; Yalkowsky, S.H. Solubilization of rapamycin. Int. J. Pharm. 2001, 213, 25-29.

6. Crowe, A.; Bruelisauer, A.; Duerr, L. Absorption and intestinal metabolism of SDZ-RAD and rapamycin in rats. Drug Metab. Dispos. 1999, 27, 627-632.

7. Gu, J.X.; Ruppen, M.E. Proline CCI-779, Production of and Uses Therefor, and Two-step Enzymatic Synthesis of Proline CCI-779 and CCI-779. US Patent 20050234086A1, 12 April 2005.

8. Shaw, C.C. Treating Rapamycin with Chlorotrimethylsilane in an Inert Solvent in the Presence of a Suitable Base to Provide Rapamycin 31,42-bis-Trimethylsilyl ether; Treating with Dilute Acid to prOvide rapamycin 31-Trimethylsilyl Ether. US Patent 6277983, 21 August 2001.

9. Niznansky, D.; Rehspringer, J.L. Infrared study of SiO 2 sol to gel evolution and gel aging. J. Non-Cryst. Solids 1995, 180, 191-196. 
10. Yokogawa, H.; Yokogawa, M. Hydrophobic silica aerogels. J. Non-Cryst. Solids 1995, 186, 23-29.

11. Latthe, S.S.; Nadargi, D.Y. TMOS based water repellent silica thin films by co-precursor method using TMES as a hydrophobic agent. Appl. Surf. Sci. 2009, 225, 3600-3604.

12. Orcel, O.; Hench, L.L. Effect of formamide additive on the chemistry of silica sol-gels II. gel structure. J. Non-Cryst. Solids 1988, 105, 223-231.

13. Cao, S.; Zhou, X.B.; Zhang, H. Novel cross-link breaker based on zwitterion structure: Synthesis, structure and druggability studies. Eur. J. Med. Chem. 2013, 68, 89-95.

14. Gupta, N. Process for the Preparation of Temsirolimus and Its Intermediates. US Patent 20110184167A1, 28 July 2011.

15. Lee, K.C. Process for Preparation of Temsirolimus. US Patent 20100249415A1, 30 September 2010.

16. Swindells, D.C.; White, P.S.; Findlay, J.A. The X-ray crystal structure of rapamycin, $\mathrm{C}_{51} \mathrm{H}_{79} \mathrm{NO}_{13}$. Can. J. Chem. 1978, 56, 2491-2492.

17. Xie, L.; Huang, J.; Zuo, J. 41-Azido-41-de-oxy-rapamycin. Acta Crystallogr. E 2012, 68 (Pt. 4), o1206-o1207.

18. Xie, L.; Zuo, J.; Yang, G. 40-De-oxy-40(S)-iodo-rapamycin. Acta Crystallogr. E 2012, 68 (Pt. 8), o2331.

Sample Availability: Samples of the compounds 1-11 are available from the authors.

(C) 2014 by the authors; licensee MDPI, Basel, Switzerland. This article is an open access article distributed under the terms and conditions of the Creative Commons Attribution license (http://creativecommons.org/licenses/by/3.0/). 